\title{
SPI-based drought category prediction using loglinear models
}

\author{
Elsa E. Moreira ${ }^{a, *}$, Carlos A. Coelho ${ }^{a}$, Ana A. Paulo ${ }^{b}$, \\ Luís S. Pereira $^{b}$, João T. Mexia ${ }^{a}$
}

a Centro de Matemática e Aplicações, Faculdade de Ciências e Tecnologia, Universidade Nova de Lisboa, 2829-516 Caparica, Portugal

${ }^{\mathrm{b}}$ Centro de Estudos de Engenharia Rural, Instituto Superior de Agronomia, Universidade Técnica de Lisboa, Tapada da Ajuda, 1349-017 Lisboa, Portugal

Received 8 January 2007; received in revised form 1 February 2008; accepted 5 March 2008

\author{
KEYWORDS \\ Standardized Precipita- \\ tion Index; \\ Three-dimensional \\ loglinear models; \\ Drought class \\ transitions; \\ Odds; \\ Prediction; \\ Portugal
}

\begin{abstract}
Summary Loglinear modeling for three-dimensional contingency tables was used with data from 14 rainfall stations located in Alentejo and Algarve region, southern of Portugal, for short term prediction of drought severity classes. Loglinear models were fitted to drought class transitions derived from Standardized Precipitation Index (SPI) time series computed in a 12-month time scale. Quasi-association loglinear models proved to be the most adequate in fitting all the 14 data series. Odds and respective confidence intervals were calculated in order to understand the drought evolution and to estimate the drought class transition probabilities. The validation of the predictions was performed for the 2004-2006 drought, particularly for periods when the drought was initiating and establishing, and when it was dissipating. Despite the contingency tables of drought class transitions present a strong diagonal tendency, results of three-dimensional loglinear modeling present good results when comparing predicted and observed drought classes with 1 and 2 months lead for those 14 sites. Only for a few cases predictions did not fully match the observed drought severity, mainly for 2-month lead and when the SPI values are near the limit of the severity class. It could be concluded that loglinear prediction of drought class transitions is a useful tool for short term drought warning.
\end{abstract}

(c) 2008 Elsevier B.V. All rights reserved.

\section{Introduction}

Successful water management to cope with drought requires the understanding of the governing processes and causes. Numerous drought definitions exist, mainly

\footnotetext{
Corresponding author. Tel.: +351 936282422.

E-mail addresses: efnm@fct.unl.pt (E.E. Moreira), cmac@ fct.unl.pt (C.A. Coelho), apaulo@isa.utl.pt (A.A. Paulo), lspereira@ isa.utl.pt (L.S. Pereira), jtm@fct.unl.pt (J.T. Mexia).
}

0022-1694/\$ - see front matter (c) 2008 Elsevier B.V. All rights reserved. doi:10.1016/j.jhydrol.2008.03.002 
depending upon the perspectives of water users and managers (NDMC, 2006). Drought is defined herein as a natural but temporary imbalance of water availability, consisting of a persistent lower-than-average precipitation, of uncertain frequency, duration and severity, of unpredictable or difficult to predict occurrence, resulting in diminished water resources availability, and reduced carrying capacity of the ecosystems (Pereira et al., 2002).

It is important to recognize the low predictability of droughts, which make drought both a hazard and a disaster: a hazard because it is a natural accident of unpredictable occurrence but of recognizable recurrence, and a disaster because it corresponds to the failure of the precipitation regime, causing the disruption of the water supply to the natural and agricultural ecosystems as well as to other human activities. The hazard and disaster nature of droughts makes it important to develop prediction tools, including probabilistic ones, which may support early warning for timely implementation of preparedness and mitigation measures (Wilhite et al., 2000). The definition above is in agreement with the recent statement on droughts by the AMS (2004), where particular attention is given to the disaster nature of droughts, their impacts and needs for prediction and warning.

Droughts have a slow initiation and they are usually only recognized when the drought is already established. They are of long duration, and usually affect large areas. Their impacts are pervasive. Forecasting of when a drought is likely to begin or to come to an end is extremely difficult (NDMC, 2006). An adequate lead-time, i.e. the period between the release of the prediction and the actual onset of the predicted drought hazard, is often more important than the accuracy of the prediction. The lead-time makes it possible for decision and policy makers to timely implement policies and measures to mitigate the effects of drought (Nichols et al., 2005).

For drought monitoring and warning, meteorologists and hydrologists have developed indices, which depend on hydro-meteorological parameters or rely on probabilities of drought occurrence (Vogt and Somma, 2000; Hayes, 2006). Drought indices based on one or more variables are commonly used to identify and monitor drought at different time scales. The Standardized Precipitation Index (SPI), although recently developed (McKee et al., 1993, 1995), is widely used because it allows a reliable and relatively easy comparison between different locations and climates. Several drought indices have already been used in Portugal, particularly in recent studies applied to the Alentejo region. Comparisons among drought indices show the appropriateness of using the Standardized Precipitation Index (SPI) to characterize droughts in Alentejo (Paulo et al., 2003; Paulo and Pereira, 2006).

Developing prediction and early warning tools appropriate to the climatic and agricultural conditions prevailing in different drought prone areas is a current research challenge. Predictions may refer to simple relationships between precipitation and surface temperature anomalies that relate to seasonal rainfall (Cordery, 1999) or to climate forecasts useful for improving the warning lead-time of droughts using drought indices (Steinemann, 2006). A stochastic approach was recently developed by Cancelliere et al. (2007) to forecast monthly SPI for various time scales.
Present trends also include neural networks and stochastic models applied to time series of precipitation or streamflow (Mishra and Desai, 2006; Thyer et al., 2006). Recent developments in drought forecasting at large and regional scales using the SPI are reported by Bordi and Sutera (2007) and Cacciamani et al. (2007), respectively. At present, more powerful tools explore teleconnections, mainly in relation to the El Niño-southern oscillation (ENSO) phenomenon (Cordery and McCall, 2000; Tadesse et al., 2005; Kim et al., 2006), whose influences on atmospheric circulation patterns are apparent in regions very far from the Pacific Ocean, and the North Atlantic oscillation (Wedgbrow et al., 2002).

Atmospheric circulation patterns governing wet and dry rainfall regimes in Portugal are quite complex, which makes it difficult to explore global circulation for prediction of droughts (Trigo et al., 2004; Santos et al., 2005); however, conditions determining drought events are well known (Santos et al., 2006). The stochastic properties of the SPI time series were explored for predicting drought class transitions using Markov chains modeling (Paulo et al., 2005; Paulo and Pereira, 2007) and loglinear models were also first used with this purpose (Paulo et al., 2005). Loglinear models were successfully applied to analyse drought class transitions and to search for impacts of climate change on drought frequency and severity (Moreira et al., 2006). As part of a study aimed at developing drought risk management tools, the SPI time series with the 12-month time scale for 14 rainfall stations in the region of Alentejo, southern Portugal, were analyzed using the loglinear models (Nelder, 1974; Agresti, 1990). The objective is modeling two consecutive transitions between drought classes derived from the SPI to determine the most probable drought class 1 and 2 months ahead knowing the drought classes in two preceding months. The objective of this research is to search for a model able to use currently monitored data and to predict when a drought is initiating, how it is developing when installed, and when it is terminating. Creating a lead prediction, even at short time scale, improves the usefulness of drought monitoring and related information (Hayes et al., 2007). Adopting the SPI drought severity classes, a drought is initiating when the near normal drought class tends to be maintained or aggravating, i.e. when monthly predictions of drought class transitions indicate a probable increase in severity. A drought is dissipating when transitions from severe/ extreme drought classes to moderate and near normal classes occur.

This approach has to be later combined with other predictions of stochastic nature (e.g. Paulo and Pereira, 2007; Cancelliere et al., 2007) and weather regime modeling. Large scale atmospheric circulation in terms of low frequency components (time scales of $1-3$ months) tends to cluster around certain weather regimes whose resident and recurrence times, as well as the transition probabilities, seem to be well characterized by hidden Markov chains, as observed for the Euro-Atlantic region (Kondrashov et al., 2004; Deloncle et al., 2007). Weather regimes are also probabilistically linked to local climate conditions of precipitation and temperature since certain regimes are more favorable than others for drought conditions. In particular for Iberia, the influence of blocking and the North Atlantic oscillation (NAO) regimes has been studied in terms of 
seasonal conditioning of river flows and precipitation (Trigo et al., 2004). Further combining stochastic and weather regimes approaches should improve predictions and hopefully extend them to 3 months lead time or to seasonal predictions.

These short time drought predictions are important for warning farmers about the probable initiation or establishment of a drought, about its continuation or its probable termination in a few months. This information may help them to make decisions to cope with that predicted situation. Several studies refer to the usefulness of climatic information for agricultural decision making (Yevjevich et al., 1983; Ogallo et al., 2000). Short time drought predictions may also be used to alert water managers and decision or policy makers about the need to enforce appropriate preparedness measures before a drought is effectively installed, or to prepare for a post-drought period. The Australian experience constitutes a good example of moving from drought disaster mitigation into risk management
(Wilhite, 2005). Thus, this loglinear monthly prediction approach is to be later combined with other prediction tools of different nature, including stochastic and weather regime transitions models, to improve predictions and hopefully extend them to 3 months. The model approach is presented and results for two periods, when the 2004-2006 drought was initiating and was dissipating, are discussed.

\section{Data: SPI drought classes}

Input data to this study consists of SPI monthly values computed in a 12-month time scale for the period from September 1932 to June 2006. This index was derived from monthly rainfall data from 14 meteorological stations. The location of these meteorological stations is given in Fig. 1. The average monthly distribution of precipitation in Alentejo is also presented in Fig. 1, which shows a typical Mediterranean precipitation pattern, with

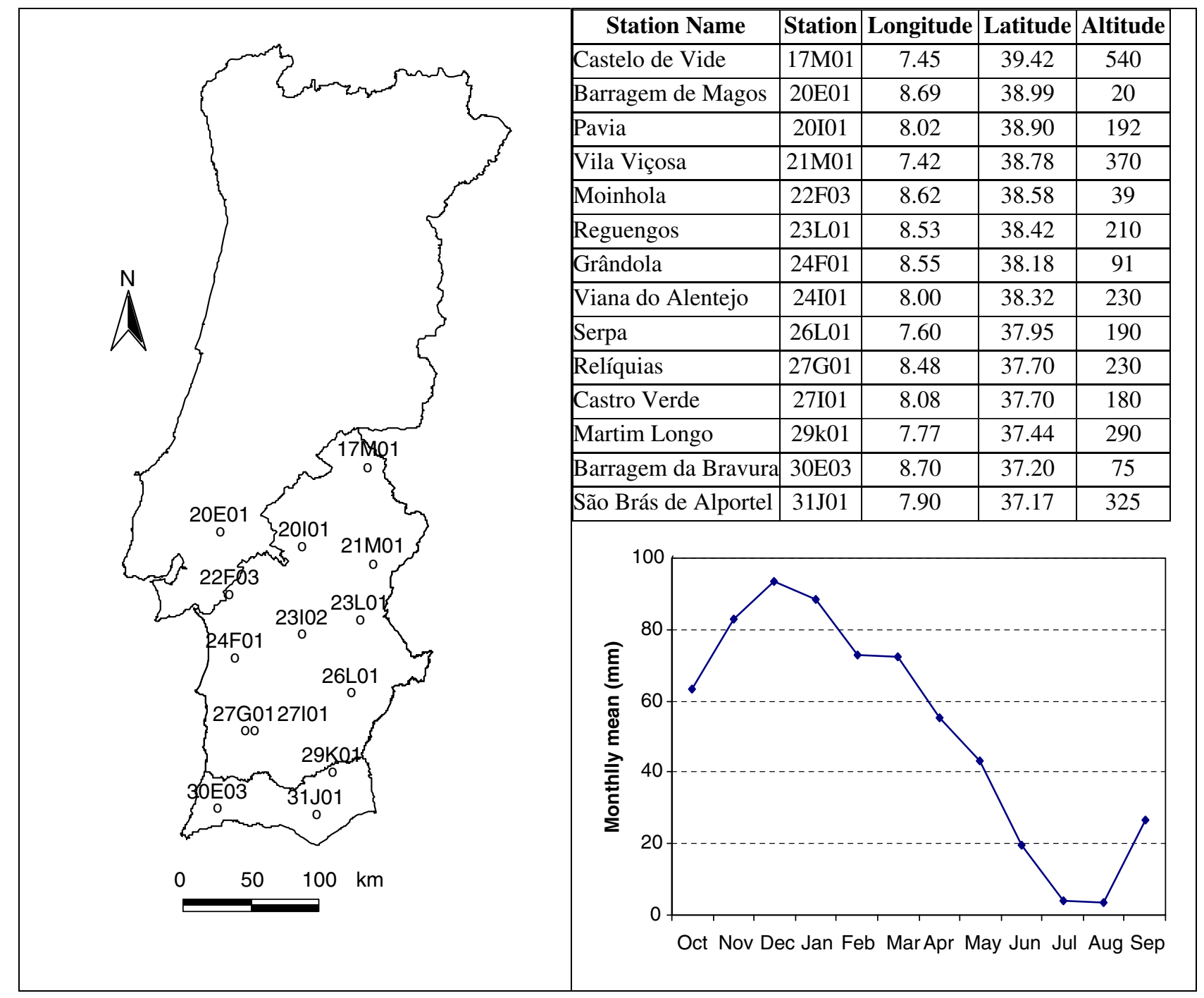

Figure 1 Selected rainfall stations in Alentejo and Algarve and monthly mean of a real precipitation in Alentejo computed from 49 rainfall stations $(1931 / 1932$ to $1998 / 1999)$. 
rainfall concentration during the autumn and winter months, and a very dry summer.

The SPI was used for the identification of drought events and to evaluate their severity. In this study, the time series on transitions among drought classes are used. The severity drought classes adopted are defined in Table 1. They are modified from those proposed by Mckee et al. (1993, 1995) by grouping the severe and extremely severe drought classes for modeling purposes since transitions referring to the extremely severe droughts are much less frequent than for other classes; thus, a possible bias is avoided.

The methods used to assess the quality of precipitation data series and to compute the SPI at the 12-month time scale are described by Paulo et al. (2003, 2005). Annual precipitation data sets were investigated for randomness, homogeneity and absence of trends using the autocorrelation test (Kendall $\tau$ ), the Mann-Kendall trend test and the homogeneity tests of Mann-Whitney for the mean and the variance (Helsel and Hirsch, 1992). In addition, the appropriateness for using the gamma distribution to compute the 12-month time scale SPI was verified with non-parametric tests.

The SPI may be computed on shorter or longer time scales, which reflect different lags in the response of water cycle to precipitation anomalies. However, the SPI values computed from precipitation data sets having different lengths are highly correlated and consistent if the gamma distributions of precipitation relative to those different time periods are similar. When the time scale is short, for instance 3-month, the SPI reflect the seasonality of the data and is more appropriate to identify drought impacts on agriculture. As the time scale increases the SPI responds more slowly to changes in precipitation, and results for the 12 -month time scale identify dry periods of long duration which relate with the global impact of drought on hydrologic regimes and water resources of a region (Paulo et al., 2003; Paulo and Pereira, 2006). For this reason, the 12-month time scale was selected. Examples of SPI 12-month time scale for several locations in the target region of Alentejo are shown by Moreira et al. (2006).

\section{Loglinear models with three-dimensions}

\section{Three-dimensions loglinear models}

Loglinear modeling (Agresti, 1990), which describe association patterns among categorical variables, is performed

Table 1 Drought class classification of SPI (modified from Mckee et al., 1993)

\begin{tabular}{lll}
\hline Code & Drought classes & SPI values \\
\hline 1 & Non-drought & SPI $\geqslant 0$ \\
2 & Near normal & $-1<\mathrm{SPI}<0$ \\
3 & Moderate & $-1.5<\mathrm{SPI} \leqslant-1$ \\
4 & Severe/extreme & $\mathrm{SPI} \leqslant-1.5$ \\
\hline
\end{tabular}

for the cell counts in contingency tables. The Poisson sampling model for counts is usually used for counts in contingency tables and assumes that they are independent Poisson random variables. Three-dimensional loglinear models aim at fitting the observed frequencies of transitions between each drought class, denoted as $O_{i j k}$, and to model the corresponding expected frequencies, denoted as $E_{i j k}$, which are the estimates of the observed frequencies for each cell of a three-dimensional contingency table (Table 2).

The contingency table, considering the objectives of this study, has three classification criterions (A, B and C) with levels $i, j$ and $k, \quad(i=1, \ldots, 4), \quad(j=1, \ldots, 4)$ and $(k=$ $1, \ldots, 4)$, respectively. Criterions $A, B$ and $C$ refer to drought classes at months $t-2, t-1$ and $t$, respectively. The levels $1, \ldots, 4$ are associated to the drought classes: 1 to the 'nondrought' class, 2 to the 'near normal drought' class, 3 to the 'moderate drought' class, and 4 to the 'severe/extreme drought' class.

The observed frequencies $\left(O_{i j k}\right)$ are the response variable for the loglinear models and refer to the observed number of transitions between the drought class $i$ at month $t-2$ (criterion A) and drought class $j$ at month $t-1$ (criterion B) and drought class $k$ at month $t$ (criterion $C$ ). The observation $O_{111}$ is the number of times that a given site stays for three consecutive months in drought class 1 ('Nondrought'). So, the three-dimensional loglinear models allow modeling the expected frequencies of drought class transitions corresponding to a 2-month step transition from drought class $i$ to class $j(t-2 \rightarrow t-1)$ and from class $j$ to class $\mathrm{k}(t-1 \rightarrow t)$.

Several models for three-dimensional contingency tables were tested. The quasi-association model is the one that better fitted the observed frequencies. For the threedimensional contingency table above, this model is given by

$$
\begin{aligned}
\log E_{i j k}= & \lambda+\lambda_{i}^{\mathrm{A}}+\lambda_{j}^{\mathrm{B}}+\lambda_{k}^{\mathrm{C}}+\beta u_{i} v_{j}+\alpha u_{i} w_{k}+\eta v_{j} w_{k}+\tau u_{i} v_{j} w_{k} \\
& +\delta_{1 i} l(i=j)+\delta_{2 i} l(i=k)+\delta_{3 j} l(j=k)+\delta_{4 i} l(i=j=k)
\end{aligned}
$$

where $\lambda$ is the constant term in the model, $\lambda_{i}^{A}$ represents the $i$ th level for criterion $A, \lambda_{j}^{B}$ represents the $j$ th level for criterion $\mathrm{B}$ and $\lambda_{k}^{C}$ represents the $k$ th level for criterion $C$, $u_{i}, v_{j}$ and $w_{k}$ are, respectively, the ith level score for criterion $\mathrm{A}$, the $j$ th level score of criterion $\mathrm{B}$, and the $k$ th level score for criterion $C$, with $i, j$ and $k \in\{1,2,3,4\}$ (usually it is taken $u_{i}=i, v_{j}=j$ and $w_{k}=k$ ). In this model, $\beta, \alpha, \eta$ and $\tau$ are the linear association parameters, and $\delta_{1 i}, \delta_{2 i}$ and $\delta_{4 i}$ are parameters associated to the ith diagonal element of $\mathrm{A}$ criterion and $\delta_{3 j}$ to the $j$ th diagonal element of $B$ criterion. $I$ is the indicator function defined as usual by

$$
I \text { (condition) }= \begin{cases}0 & \text { if condition true } \\ 1 & \text { if condition false }\end{cases}
$$

In loglinear models with Poisson sampling, the errors are Poisson random variables and the parameter estimation for loglinear models is performed with the Maximum Likelihood Method. The residual deviance given by

$D=2 \sum_{i} \sum_{j} \sum_{k} O_{i j k} \log \left(O_{i j k} / E_{i j k}\right)$ 
Table 2 Three-dimensional contingency table for two consecutive transitions between drought classes

\begin{tabular}{|c|c|c|c|c|c|c|c|c|c|c|c|c|c|c|c|c|}
\hline \multirow{4}{*}{$\begin{array}{l}\text { Drought class at } \\
\text { month } t-2\end{array}$} & \multicolumn{16}{|c|}{ Drought class month $t$} \\
\hline & \multicolumn{4}{|l|}{1} & \multicolumn{4}{|l|}{2} & \multicolumn{4}{|l|}{3} & \multicolumn{4}{|l|}{4} \\
\hline & \multicolumn{4}{|c|}{$\begin{array}{l}\text { Drought class month } \\
t-1\end{array}$} & \multicolumn{4}{|c|}{$\begin{array}{l}\text { Drought class month } \\
t-1\end{array}$} & \multicolumn{4}{|c|}{$\begin{array}{l}\text { Drought class month } \\
t-1\end{array}$} & \multicolumn{4}{|c|}{$\begin{array}{l}\text { Drought class month } \\
t-1\end{array}$} \\
\hline & 1 & 2 & 3 & 4 & 1 & 2 & 3 & 4 & 1 & 2 & 3 & 4 & 1 & 2 & 3 & 4 \\
\hline 1 & $O_{111}$ & $O_{121}$ & $O_{131}$ & $O_{141}$ & $O_{112}$ & $O_{122}$ & $O_{132}$ & $O_{142}$ & $O_{113}$ & $O_{123}$ & $O_{133}$ & $O_{143}$ & $O_{114}$ & $O_{124}$ & $O_{134}$ & $O_{144}$ \\
\hline 2 & $O_{211}$ & $\mathrm{O}_{221}$ & $\mathrm{O}_{231}$ & $O_{241}$ & $\mathrm{O}_{212}$ & $\mathrm{O}_{222}$ & $\mathrm{O}_{232}$ & $\mathrm{O}_{242}$ & $\mathrm{O}_{213}$ & $\mathrm{O}_{223}$ & $\mathrm{O}_{233}$ & $\mathrm{O}_{243}$ & $\mathrm{O}_{214}$ & $\mathrm{O}_{224}$ & $\mathrm{O}_{234}$ & $\mathrm{O}_{244}$ \\
\hline 3 & $O_{311}$ & $O_{321}$ & $O_{331}$ & $O_{341}$ & $O_{312}$ & $\mathrm{O}_{322}$ & $\mathrm{O}_{332}$ & $\mathrm{O}_{342}$ & $\mathrm{O}_{313}$ & $\mathrm{O}_{323}$ & $\mathrm{O}_{333}$ & $\mathrm{O}_{343}$ & $O_{314}$ & $\mathrm{O}_{324}$ & $\mathrm{O}_{334}$ & $O_{344}$ \\
\hline 4 & $O_{411}$ & $O_{421}$ & $O_{431}$ & $O_{441}$ & $\mathrm{O}_{412}$ & $\mathrm{O}_{422}$ & $\mathrm{O}_{432}$ & $\mathrm{O}_{442}$ & $O_{413}$ & $O_{423}$ & $O_{433}$ & $O_{443}$ & $O_{414}$ & $O_{424}$ & $O_{434}$ & $O_{444}$ \\
\hline
\end{tabular}

is proved to have approximate chi-square distribution with degrees of freedom equal to the number cells in the contingency table minus the number of linearly independent estimated model parameters, see Nelder (1974) and Agresti (1990). To evaluate the goodness of fitting of a loglinear model a chi-square test can be used, see again Nelder (1974) and Agresti (1990). The null hypothesis tested is: the model fits well data. Thus, the null hypothesis is not rejected for those models having a residual deviance not exceeding the chi-square quantile for a probability $1-\alpha=0.95$ and the corresponding degrees of freedom. In other words, all the models presenting a test $p$-value exceeding the chosen significance level of $\alpha=0.05$ are considered well fitted. The quasi-association (QA) model (Eq. (1)) proved to be the most adequate for all the 14 sites.

Several cases of very low expected frequencies, even < 1 , were obtained. This situation causes difficulties when predicting less frequent transitions (Deloncle et al., 2007) and may be questioned for the application of chi- square tests for fitting and asymptotic results commonly used in inference associated with linear generalized models (e.g. Rao, 1973). However, Bhattacharya and Chan (1996) concluded that the classic chi-square test and the approximations based in this test have a very good performance and are therefore appropriate for expected frequencies less than 1.

The backward elimination method (Agresti, 1990) was applied to each complete QA model (Eq. (1)) adjusted to each location data set to reduce the number of model parameters without significant loss of information. This method allows the selection of an alternative sub-model eliminating the less significant parameters of the QA model, as illustrated in Appendix 1 for Grândola.

For all sites, the adjusted models have test $p$-values exceeding $\alpha=0.05$, which means that none of them is to be rejected. For each site the selected sub-model obtained from backward elimination, the respective degrees of freedom (d.f.), residual deviance and $p$-values are presented in Table 3 .

Table 3 Selected loglinear QA submodels, degrees of freedom, residual deviances and $p$-values for all sites

\begin{tabular}{|c|c|c|c|c|}
\hline Site & Selected submodel & d.f. & $\begin{array}{l}\text { Residual } \\
\text { deviance }\end{array}$ & $p$-Value \\
\hline Castelo de Vide & $\log E_{i j k}=\lambda+\lambda_{i}^{\mathrm{A}}+\lambda_{j}^{\mathrm{B}}+\lambda_{k}^{\mathrm{C}}+\beta u_{i} v_{j}+\eta v_{j} w_{k}+\delta_{1 i} l(\boldsymbol{i}=\boldsymbol{j})+\delta_{2 i} l(\boldsymbol{i}=\mathbf{k})+\delta_{3 j} l(\boldsymbol{j}=\mathbf{k})$ & 40 & 31.85 & 0.8175 \\
\hline Barragem de Magos & $\log E_{i j k}=\lambda+\lambda_{i}^{\mathrm{A}}+\lambda_{j}^{\mathrm{B}}+\lambda_{k}^{\mathrm{C}}+\beta u_{i} v_{j}+\eta v_{j} w_{k}+\delta_{1 i} I(i=j)+\delta_{3 j} I(j=k)$ & 44 & 41.28 & 0.5889 \\
\hline Pavia & $\log E_{i j k}=\lambda+\lambda_{i}^{A}+\lambda_{j}^{B}+\lambda_{k}^{C}+\beta u_{i} v_{j}+\eta v_{j} w_{k}+\delta_{1 i} l(i=j)+\delta_{3 j} l(j=k)$ & 44 & 28.52 & 0.9659 \\
\hline Vila Viçosa & $\log E_{i j k}=\lambda+\lambda_{i}^{\mathrm{A}}+\lambda_{j}^{\mathrm{B}}+\lambda_{k}^{\mathrm{C}}+\beta u_{i} v_{j}+\eta v_{j} w_{k}+\delta_{1 i} l(i=j)+\delta_{2 i} l(\boldsymbol{i}=k)+\delta_{3 j} l(j=k)$ & 40 & 17.24 & 0.9994 \\
\hline Moinhola & $\log E_{i j k}=\lambda+\lambda_{i}^{\mathrm{A}}+\lambda_{j}^{\mathrm{B}}+\lambda_{k}^{\mathrm{C}}+\beta u_{i} v_{j}+\eta v_{j} w_{k}+\delta_{1 i} l(\boldsymbol{i}=j)+\delta_{2 i} l(\boldsymbol{i}=k)+\delta_{3 j} l(j=k)$ & 40 & 26.75 & 0.9462 \\
\hline Reguengos & $\log E_{i j k}=\lambda+\lambda_{i}^{A}+\lambda_{j}^{B}+\lambda_{k}^{C}+\beta u_{i} v_{j}+\eta v_{j} w_{k}+\delta_{1 i} l(i=j)+\delta_{2 i} l(i=k)+\delta_{3 j} l(j=k)$ & 40 & 39.97 & 0.4716 \\
\hline Grândola & $\log E_{i j k}=\lambda+\lambda_{i}^{A}+\lambda_{j}^{B}+\lambda_{k}^{C}+\beta u_{i} v_{j}+\eta v_{j} w_{k}+\delta_{1 i} l(i=j)+\delta_{2 i} l(i=k)+\delta_{3 j} l(j=k)$ & 40 & 30.34 & 0.8655 \\
\hline Viana do Alentejo & $\log E_{i j k}=\lambda+\lambda_{i}^{\mathrm{A}}+\lambda_{j}^{\mathrm{B}}+\lambda_{k}^{\mathrm{C}}+\beta u_{i} v_{j}+\eta v_{j} w_{k}+\delta_{2 i} l(i=k)+\delta_{4 j} l(j=k)$ & 44 & 14.81 & 0.9999 \\
\hline Serpa & $\log E_{i j k}=\lambda+\lambda_{i}^{\mathrm{A}}+\lambda_{j}^{\mathrm{B}}+\lambda_{k}^{\mathrm{C}}+\beta u_{i} v_{j}+\eta v_{j} w_{k}+\delta_{1 i} l(\boldsymbol{i}=\boldsymbol{j})+\delta_{2 i} l(\boldsymbol{i}=k)+\delta_{3 j} l(j=k)$ & 40 & 32.45 & 0.7962 \\
\hline Reliquias & $\log E_{i j k}=\lambda+\lambda_{i}^{\mathrm{A}}+\lambda_{j}^{\mathrm{B}}+\lambda_{k}^{\mathrm{C}}+\beta u_{i} v_{j}+\eta v_{j} w_{k}+\delta_{4 j} l(j=k)$ & 48 & 35.05 & 0.9183 \\
\hline Castro Verde & $\log E_{i j k}=\lambda+\lambda_{i}^{\mathrm{A}}+\lambda_{j}^{\mathrm{B}}+\lambda_{k}^{\mathrm{C}}+\beta u_{i} v_{j}+\eta v_{j} w_{k}+\delta_{1 i} l(i=j)+\delta_{3 j} l(j=k)$ & 48 & 19.73 & 0.9990 \\
\hline Barragem da Bravura & $\log E_{i j k}=\lambda+\lambda_{i}^{\mathrm{A}}+\lambda_{j}^{\mathrm{B}}+\lambda_{k}^{\mathrm{C}}+\beta u_{i} v_{j}+\eta v_{j} w_{k}+\delta_{1 i} I(\boldsymbol{i}=j)+\delta_{3 j} l(j=k)$ & 44 & 22.61 & 0.9969 \\
\hline Martim Longo & $\log E_{i j k}=\lambda+\lambda_{i}^{\mathrm{A}}+\lambda_{j}^{\mathrm{B}}+\lambda_{k}^{\mathrm{C}}+\beta u_{i} v_{j}+\eta v_{j} w_{k}+\delta_{1 i} l(\boldsymbol{i}=j)+\delta_{3 i} l(\boldsymbol{i}=k)+\delta_{4 j} l(j=k)$ & 40 & 42.79 & 0.3523 \\
\hline São Brás de Alportel & $\log E_{i j k}=\lambda+\lambda_{i}^{\mathrm{A}}+\lambda_{j}^{\mathrm{B}}+\lambda_{k}^{\mathrm{C}}+\beta u_{i} v_{j}+\eta v_{j} w_{k}+\delta_{1 i} l(i=j)+\delta_{3 i} l(i=k)+\delta_{4 j} l(j=k)$ & 40 & 27.76 & 0.9283 \\
\hline
\end{tabular}


Table 4 Observed versus expected frequencies of drought class transitions from month $t-2$ to month $t-1$ to month $t$ : for Grândola, SPI 12 months time scale

\begin{tabular}{|c|c|c|c|c|c|c|c|c|c|c|c|c|c|c|c|c|}
\hline \multirow{4}{*}{ Drought class month $t-2$} & \multicolumn{16}{|c|}{ Drought class month $t$} \\
\hline & 1 & & & & 2 & & & & 3 & & & & 4 & & & \\
\hline & \multicolumn{16}{|c|}{ Drought class month $t-1$} \\
\hline & 1 & 2 & 3 & 4 & 1 & 2 & 3 & 4 & 1 & 2 & 3 & 4 & 1 & 2 & 3 & 4 \\
\hline \multicolumn{17}{|l|}{ Observed frequencies } \\
\hline 1 & 357 & 9 & 0 & 0 & 33 & 28 & 0 & 0 & 0 & 4 & 0 & 0 & 0 & 1 & 0 & 0 \\
\hline 2 & 29 & 27 & 0 & 0 & 9 & 158 & 8 & 1 & 0 & 22 & 15 & 0 & 0 & 2 & 6 & 2 \\
\hline 3 & 4 & 2 & 3 & 0 & 0 & 18 & 11 & 1 & 0 & 3 & 25 & 3 & 0 & 0 & 5 & 10 \\
\hline 4 & 0 & 0 & 1 & 0 & 0 & 5 & 4 & 3 & 0 & 0 & 3 & 8 & 0 & 0 & 3 & 51 \\
\hline \multicolumn{17}{|l|}{ Expected frequencies } \\
\hline 1 & 355.7 & 10.2 & 0.1 & 0.0 & 32.6 & 26.5 & 0.6 & 0.0 & 1.6 & 3.0 & 0.8 & 0.0 & 0.1 & 0.5 & 0.3 & 0.1 \\
\hline 2 & 32.6 & 26.5 & 0.6 & 0.0 & 7.0 & 160.1 & 8.7 & 0.3 & 0.4 & 19.5 & 12.4 & 0.8 & 0.0 & 3.0 & 4.1 & 3.0 \\
\hline 3 & 1.6 & 3.0 & 0.8 & 0.0 & 0.4 & 19.6 & 12.8 & 0.8 & 0.0 & 3.2 & 24.5 & 3.2 & 0.0 & 0.3 & 5.7 & 8.7 \\
\hline 4 & 0.1 & 0.4 & 0.3 & 0.0 & 0.0 & 2.9 & 3.9 & 2.8 & 0.0 & 0.3 & 5.2 & 8.0 & 0.0 & 0.1 & 2.8 & 50.7 \\
\hline
\end{tabular}

Drought classes: 1 , non-drought; 2 , near normal drought; 3 , moderate drought; 4 , severe/extreme drought.

When the parameters of each sub-model (Table 3 ) are estimated, the expected frequencies for each cell can be computed. The observed versus expected frequencies for the Grândola site are presented in Table 4 as an example. Results for all sites show a similar agreement between observed and expected frequencies. A strong diagonal tendency is apparent, which indicates a trend for persistency of droughts in the same drought class and constitutes an additional difficulty in drought prediction. Results from a former study using loglinear models for two-dimensional contingency tables also indicate that, given an initial state, the more probable class 1 month ahead is the present one (Paulo et al., 2005). This trend is expected because "droughts are self-perpetuating", i.e., "if an area is already experiencing drought conditions, it is more likely to continue in a drought"' (NSSTC, 2003).

\section{Odds and respective confidence intervals}

An odds is a ratio of expected frequencies, ranging 0 to $+\infty$, and represents the number of times that it is more, less, or equally probable the occurrence of a certain event instead of another. The selected odds for three-dimensional models are defined as

$\Omega_{k l \mid i j}=\frac{E_{i j k}}{E_{i j l}}, \quad k \neq l$

meaning that, 1 month from now, it is $\Omega_{k l \mid i j}$ times more, less, or equally probable that a specific site is in class $k$ instead of class $l$, given that at present it is in class $j$, and 1 month before it was in class $i$, with $i, j, k$ and $l \in$ $\{1,2,3,4\}$ and $k \neq l$.

The logarithm of odds of a complete QA model is given by

$$
\begin{aligned}
\log E_{i j k}-\log E_{i j l}= & \lambda_{k}^{c}-\lambda_{l}^{c}+\alpha u_{i} w_{k}-\alpha u_{i} w_{l}+\eta v_{j} w_{k} \\
& -\eta v_{j} w_{l}+\tau u_{i} v_{j} w_{k}-\tau u_{i} v_{j} w_{l}+\delta_{2 i} l(i=k) \\
& -\delta_{2 i} l(i=l)+\delta_{3 j} l(j=k)-\delta_{3 j} l(j=l) \\
& +\delta_{4 i} l(i=j=k)-\delta_{4 i} l(i=j=l)
\end{aligned}
$$

The estimates of the corresponding odds are calculated by exponentiation of the result obtained when replacing the model parameters in Eq. (4) by their estimates obtained from the fit of the loglinear model given in Table 3 for every sites.

For large sample $\Omega_{k l \mid i j}$ have asymptotic normal distribution and the $\log$ transform $\log \Omega_{k l \mid i j}$, which is equal to $\log E_{i j k}-\log E_{i j l}$, converges more rapidly to a normal distribution. Since, for the Poisson sampling an estimator of the asymptotic standard error $\sqrt{\operatorname{Var}\left(\log \Omega_{k l \mid i j}\right)}$ can be obtained, thus the asymptotic confidence intervals for the associated with a probability $1-\alpha$

$$
\begin{aligned}
& {\left[\log \Omega_{k l \mid i j}-z_{1-\alpha / 2} \sqrt{\overline{\operatorname{Var}\left(\log \Omega_{k l \mid i j}\right)}},\right.} \\
& \left.\log \Omega_{k l \mid i j}+z_{1-\alpha / 2} \sqrt{\operatorname{Var(\operatorname {Log}\Omega _{kl|ij})}}\right]
\end{aligned}
$$

can be derived, where $z_{1-\alpha / 2}$ is the $1-\alpha / 2$ quantile of a standard normal variable (Agresti, 1990). The asymptotic confidence intervals for the odds are then obtained by exponentiation of the corresponding asymptotic confidence intervals for the logarithm of the odds. The confidence intervals of the odds reflect the sampling variability of the observed drought transitions internal to each time series. Odds confidence intervals, besides reflecting this variability, indicate also if a given odds is not significantly different from 1 . When the confidence intervals for a given odds include the value 1 it means that the drought transition from class $i$ to class $j$ to class $k$ and the drought transition from class $i$ to class $j$ to class $l$, are not significantly different. If the value 1 is not included in the confidence interval of a given odds, it means that the first transition is significantly more (or less) probable than the second, according to the respective values are larger (or smaller) than 1. However, if the confidence interval of a given odds is too large the reliability of the prediction is small. 
Table 5 Estimates of the odds $O_{34 \mid i j}$ and correspondent confidence intervals for Grândola referring to estimates for month $t$ when the drought classes are known for months $t-1$ and $t-2$

$O_{34 \mid i j}$

Drought class

month $t-2$
Drought class at month $t-1$

\begin{tabular}{|c|c|c|c|c|c|c|c|c|}
\hline \multirow[t]{2}{*}{1} & \multicolumn{2}{|c|}{24.9781} & \multicolumn{2}{|c|}{6.4302} & \multicolumn{2}{|c|}{2.9922} & \multicolumn{2}{|c|}{0.2556} \\
\hline & 8.5634 & 72.8570 & 2.2045 & 18.7557 & 1.0728 & 8.3457 & 0.0499 & 1.3098 \\
\hline \multirow[t]{2}{*}{2} & \multicolumn{2}{|c|}{24.9781} & \multicolumn{2}{|c|}{6.4302} & \multicolumn{2}{|c|}{2.9922} & \multicolumn{2}{|c|}{0.2556} \\
\hline & 8.5634 & 72.8570 & 2.2045 & 18.7557 & 1.0728 & 8.3457 & 0.0499 & 1.3098 \\
\hline \multirow[t]{2}{*}{3} & \multicolumn{2}{|c|}{35.9454} & \multicolumn{2}{|c|}{9.2535} & \multicolumn{2}{|c|}{4.3060} & \multicolumn{2}{|c|}{0.3679} \\
\hline & 10.6310 & 121.5379 & 2.7368 & 31.2877 & 1.6491 & 11.2431 & 0.0744 & 1.8202 \\
\hline \multirow[t]{2}{*}{4} & \multicolumn{2}{|c|}{15.4097} & \multicolumn{2}{|c|}{3.9670} & \multicolumn{2}{|c|}{1.8460} & \multicolumn{2}{|c|}{0.1577} \\
\hline & 3.7908 & 62.6413 & 0.9759 & 16.1259 & 0.5322 & 6.4030 & 0.0340 & 0.7319 \\
\hline
\end{tabular}

In each cell the upper value are the odds estimate and the lower ones refer to the odds confidence interval.

Table 6 Expected frequencies for two consecutive transitions between drought classes for Castelo de Vide, Pavia, Serpa and São Brás de Alportel

\begin{tabular}{|c|c|c|c|c|c|c|c|c|c|c|c|c|c|c|c|c|}
\hline & \multicolumn{16}{|c|}{ Drought class month $t$} \\
\hline & \multicolumn{4}{|c|}{1} & \multicolumn{4}{|c|}{2} & \multicolumn{4}{|c|}{3} & \multicolumn{4}{|c|}{4} \\
\hline & \multicolumn{16}{|c|}{ Drought class month $t-1$} \\
\hline $\begin{array}{l}\text { Drought class } \\
\text { month } t-2\end{array}$ & 1 & 2 & 3 & 4 & 1 & 2 & 3 & 4 & 1 & 2 & 3 & 4 & 1 & 2 & 3 & 4 \\
\hline \multicolumn{17}{|c|}{ Castelo de Vide } \\
\hline 1 & 373.5 & 4.1 & 0.0 & 0.0 & 24.8 & 20.0 & 0.5 & 0.0 & 1.3 & 3.3 & 0.8 & 0.0 & 0.0 & 0.1 & 0.2 & 0.0 \\
\hline 2 & 24.8 & 20.0 & 0.5 & 0.0 & 2.6 & 155.7 & 13.5 & 0.1 & 0.1 & 26.2 & 19.0 & 0.5 & 0.0 & 1.2 & 4.0 & 1.0 \\
\hline 3 & 1.3 & 3.3 & 0.8 & 0.0 & 0.1 & 26.0 & 19.2 & 0.5 & 0.0 & 7.5 & 46.2 & 5.2 & 0.0 & 0.2 & 5.6 & 6.7 \\
\hline 4 & 0.0 & 0.1 & 0.1 & 0.0 & 0.0 & 1.1 & 3.7 & 0.9 & 0.0 & 0.2 & 5.1 & 5.9 & 0.0 & 0.0 & 2.7 & 33.4 \\
\hline \multicolumn{17}{|c|}{ Pavia } \\
\hline 1 & 328.3 & 4.7 & 0.0 & 0.0 & 34.8 & 30.5 & 0.1 & 0.0 & 0.4 & 3.1 & 0.3 & 0.0 & 0.0 & 0.2 & 0.1 & 0.0 \\
\hline 2 & 34.8 & 30.5 & 0.1 & 0.0 & 3.7 & 199.1 & 7.4 & 0.1 & 0.0 & 20.2 & 13.9 & 0.4 & 0.0 & 1.6 & 4.1 & 1.5 \\
\hline 3 & 0.4 & 3.1 & 0.3 & 0.0 & 0.0 & 20.2 & 13.9 & 0.4 & 0.0 & 2.1 & 26.2 & 2.9 & 0.0 & 0.2 & 7.7 & 10.7 \\
\hline 4 & 0.0 & 0.2 & 0.1 & 0.0 & 0.0 & 1.6 & 4.1 & 1.5 & 0.0 & 0.2 & 7.7 & 10.7 & 0.0 & 0.0 & 2.2 & 39.3 \\
\hline \multicolumn{17}{|c|}{ Serpa } \\
\hline 1 & 373.2 & 9.2 & 0.1 & 0.0 & 33.0 & 28.1 & 0.6 & 0.0 & 1.2 & 1.7 & 0.6 & 0.0 & 0.1 & 0.4 & 0.3 & 0.1 \\
\hline 2 & 32.1 & 27.3 & 0.6 & 0.0 & 6.0 & 175.9 & 6.1 & 0.2 & 0.3 & 15.4 & 9.2 & 0.7 & 0.0 & 3.6 & 4.6 & 3.2 \\
\hline 3 & 1.1 & 1.6 & 0.6 & 0.0 & 0.3 & 15.0 & 9.0 & 0.7 & 0.0 & 3.0 & 30.9 & 5.2 & 0.0 & 0.2 & 4.7 & 6.9 \\
\hline 4 & 0.1 & 0.4 & 0.3 & 0.0 & 0.0 & 3.4 & 4.3 & 2.8 & 0.0 & 0.2 & 4.4 & 6.2 & 0.0 & 0.1 & 3.0 & 37.0 \\
\hline \multicolumn{17}{|c|}{ São Brás Alportel } \\
\hline 1 & 358.9 & 5.5 & 0.0 & 0.0 & 25.3 & 25.2 & 0.2 & 0.0 & 0.7 & 3.6 & 0.6 & 0.0 & 0.0 & 0.6 & 0.2 & 0.0 \\
\hline 2 & 25.3 & 25.4 & 0.2 & 0.0 & 9.4 & 186.8 & 4.8 & 0.4 & 0.3 & 16.5 & 13.9 & 1.8 & 0.0 & 3.0 & 3.9 & 1.8 \\
\hline 3 & 0.7 & 3.5 & 0.6 & 0.0 & 0.3 & 15.9 & 13.5 & 1.8 & 0.0 & 2.3 & 34.8 & 7.9 & 0.0 & 0.4 & 10.8 & 8.0 \\
\hline 4 & 0.0 & 0.6 & 0.2 & 0.0 & 0.0 & 2.7 & 3.6 & 1.6 & 0.0 & 0.4 & 10.4 & 7.3 & 0.0 & 0.1 & 2.9 & 27.6 \\
\hline
\end{tabular}


The results for odds estimates $\Omega_{34 \mid i j}=E_{i j 3} / E_{i j 4}$ and respective confidence intervals for the site Grândola are presented as example in Table 5. Taking the case for the drought class in September and October 2005, which was $4(i=j=4)$ and the estimate of odds $\Omega_{34 \mid 44}$ was 0.1577 , with the confidence interval $[0.0340 ; 0.7319]$, because the value 1 is not included in that interval it means that it was $1 / 0.1577=6.3407$ times more likely that by November this site would be in severe/extreme drought $(k=4)$ in stead of being in moderate drought $(l=3)$ given that in September and October it was in severe/extreme drought $(i=j=4)$. Therefore, it could be said that the more

Table 7 Comparison between observed and predicted drought classes 1 and 2 months ahead $(t$ and $t+1)$ using odds estimates when the drought classes are known at months $t-1$ and $t-2$ for a period when a drought was initiating (January-December 2004)

\begin{tabular}{|c|c|c|c|c|c|c|c|c|c|c|c|c|}
\hline \multirow[t]{2}{*}{$\begin{array}{l}\text { Date } \\
\text { (month } t)\end{array}$} & \multicolumn{4}{|c|}{$\begin{array}{l}\text { Drought class at Drought class at } \\
\text { month }\end{array}$} & \multicolumn{2}{|c|}{$\begin{array}{l}\text { Drought class at } \\
\text { month } t+1\end{array}$} & \multicolumn{2}{|c|}{$\begin{array}{l}\text { Drought class at } \\
\text { month }\end{array}$} & \multicolumn{2}{|c|}{$\begin{array}{c}\text { Drought class at } \\
\text { month } \mathrm{t}\end{array}$} & \multicolumn{2}{|c|}{$\begin{array}{l}\text { Drought class at } \\
\text { month } t+1\end{array}$} \\
\hline & $t-2$ & $t-1$ & Obs. & Pred. & Obs. & Pred. & $t-2$ & $t-1$ & Obs. & Pred. & Obs. & Pred. \\
\hline \multicolumn{7}{|c|}{ Castelo de Vide } & \multicolumn{6}{|c|}{ Barragem de Magos } \\
\hline Jan-04 & 2 & 3 & 3 & 2 or 3 & 3 & 2 or 3 & 1 & 1 & 1 & 1 & 2 & 1 \\
\hline Feb-04 & 3 & 3 & 3 & 2 or 3 & 3 & 2 or 3 & 1 & 1 & 2 & 1 & 2 & 1 \\
\hline Mar-04 & 3 & 3 & 3 & 2 or 3 & 3 & 2 or 3 & 1 & 2 & 2 & 2 & 2 & 2 \\
\hline Apr-04 & 3 & 3 & 3 & 2 or 3 & 3 & 2 or 3 & 2 & 2 & 2 & 2 & 2 & 2 \\
\hline May-04 & 3 & 3 & 3 & 2 or 3 & 3 & 2 or 3 & 2 & 2 & 2 & 2 & 2 & 2 \\
\hline Jun-04 & 3 & 3 & 3 & 2 or 3 & 3 & 2 or 3 & 2 & 2 & 2 & 2 & 2 & 2 \\
\hline Jul-04 & 3 & 3 & 3 & 2 or 3 & 3 & 2 or 3 & 2 & 2 & 2 & 2 & 2 & 2 \\
\hline Aug-04 & 3 & 3 & 3 & 2 or 3 & 3 & 2 or 3 & 2 & 2 & 2 & 2 & 2 & 2 \\
\hline Sep-04 & 3 & 3 & 3 & 2 or 3 & 2 & 2 or 3 & 2 & 2 & 2 & 2 & 2 & 2 \\
\hline Oct-04 & 3 & 3 & 2 & 2 or 3 & 3 & 2 or 3 & 2 & 2 & 2 & 2 & 3 & 2 \\
\hline Nov-04 & 3 & 2 & 3 & 2 & 4 & 2 & 2 & 2 & 3 & 2 & 4 & 2 \\
\hline Dec-04 & 2 & 3 & 4 & 2 or 3 & 4 & 2 or 3 & 2 & 3 & 4 & 2 or 3 & 4 & 2 or 3 \\
\hline \multicolumn{7}{|c|}{ Pavia } & \multicolumn{6}{|c|}{ Vila Viçosa } \\
\hline Jan-04 & 2 & 2 & 3 & 2 & 3 & 2 & 1 & 2 & 2 & 2 & 2 & 2 \\
\hline Fev-04 & 2 & 3 & 3 & 2 or 3 & 3 & 2 or 3 & 2 & 2 & 2 & 2 & 2 & 2 \\
\hline Mar-04 & 3 & 3 & 3 & 2 or 3 & 3 & 2 or 3 & 2 & 2 & 2 & 2 & 2 & 2 \\
\hline Abr-04 & 3 & 3 & 3 & 2 or 3 & 3 & 2 or 3 & 2 & 2 & 2 & 2 & 2 & 2 \\
\hline Mai-04 & 3 & 3 & 3 & 2 or 3 & 3 & 2 or 3 & 2 & 2 & 2 & 2 & 2 & 2 \\
\hline Jun-04 & 3 & 3 & 3 & 2 or 3 & 3 & 2 or 3 & 2 & 2 & 2 & 2 & 2 & 2 \\
\hline Jul-04 & 3 & 3 & 3 & 2 or 3 & 3 & 2 or 3 & 2 & 2 & 2 & 2 & 2 & 2 \\
\hline Ago-04 & 3 & 3 & 3 & 2 or 3 & 3 & 2 or 3 & 2 & 2 & 2 & 2 & 2 & 2 \\
\hline Set-04 & 3 & 3 & 3 & 2 or 3 & 3 & 2 or 3 & 2 & 2 & 2 & 2 & 2 & 2 \\
\hline Out-04 & 3 & 3 & 3 & 2 or 3 & 4 & 2 or 3 & 2 & 2 & 2 & 2 & 3 & 2 \\
\hline Nov-04 & 3 & 3 & 4 & 2 or 3 & 4 & 2 or 3 & 2 & 2 & 3 & 2 & 4 & 2 \\
\hline Dez-04 & 3 & 4 & 4 & 3 or 4 & 4 & 3 or 4 & 2 & 3 & 4 & 2 or 3 & 4 & 2 or 3 \\
\hline \multicolumn{7}{|c|}{ Moinhola } & \multicolumn{6}{|c|}{ Reguengos } \\
\hline Jan-04 & 1 & 2 & 2 & 2 & 2 & 2 & 2 & 2 & 2 & 2 & 2 & 2 \\
\hline Fev-04 & 2 & 2 & 2 & 2 & 2 & 2 & 2 & 2 & 2 & 2 & 2 & 2 \\
\hline Mar-04 & 2 & 2 & 2 & 2 & 2 & 2 & 2 & 2 & 2 & 2 & 2 & 2 \\
\hline Abr-04 & 2 & 2 & 2 & 2 & 2 & 2 & 2 & 2 & 2 & 2 & 2 & 2 \\
\hline Mai-04 & 2 & 2 & 2 & 2 & 2 & 2 & 2 & 2 & 2 & 2 & 2 & 2 \\
\hline Jun-04 & 2 & 2 & 2 & 2 & 2 & 2 & 2 & 2 & 2 & 2 & 2 & 2 \\
\hline Jul-04 & 2 & 2 & 2 & 2 & 2 & 2 & 2 & 2 & 2 & 2 & 2 & 2 \\
\hline Ago-04 & 2 & 2 & 2 & 2 & 2 & 2 & 2 & 2 & 2 & 2 & 2 & 2 \\
\hline Set-04 & 2 & 2 & 2 & 2 & 2 & 2 & 2 & 2 & 2 & 2 & 2 & 2 \\
\hline Out-04 & 2 & 2 & 2 & 2 & 3 & 2 & 2 & 2 & 2 & 2 & 3 & 2 \\
\hline Nov-04 & 2 & 2 & 3 & 2 & 4 & 2 & 2 & 2 & 3 & 2 & 4 & 2 \\
\hline Dez-04 & 2 & 3 & 4 & 2 or 3 & 4 & 2 or 3 & 2 & 3 & 4 & 2 or 3 & 4 & 3 \\
\hline
\end{tabular}


Table 7 (continued)

\begin{tabular}{|c|c|c|c|c|c|c|c|c|c|c|c|c|}
\hline \multirow[t]{2}{*}{$\begin{array}{c}\text { Date } \\
\text { (month } t)\end{array}$} & \multicolumn{2}{|c|}{$\begin{array}{l}\text { Drought class at } \\
\text { month }\end{array}$} & \multicolumn{2}{|c|}{$\begin{array}{l}\text { Drought class } \\
\text { at month } t\end{array}$} & \multicolumn{2}{|c|}{$\begin{array}{l}\text { Drought class at } \\
\text { month } t+1\end{array}$} & \multicolumn{2}{|c|}{$\begin{array}{l}\text { Drought class at } \\
\text { month }\end{array}$} & \multicolumn{2}{|c|}{$\begin{array}{c}\text { Drought class at } \\
\text { month } t\end{array}$} & \multicolumn{2}{|c|}{$\begin{array}{l}\text { Drought class at } \\
\text { month } t+1\end{array}$} \\
\hline & $t-2$ & $t-1$ & Obs. & Pred. & Obs. & Pred. & $t-2$ & $t-1$ & Obs. & Pred. & Obs. & Pred. \\
\hline & \multicolumn{6}{|c|}{ Grândola } & \multicolumn{6}{|c|}{ Viana do Alentejo } \\
\hline Jan-04 & 1 & 2 & 2 & 2 & 2 & 2 & 2 & 2 & 3 & 2 & 3 & 2 \\
\hline Fev-04 & 2 & 2 & 2 & 2 & 2 & 2 & 2 & 3 & 3 & 2 or 3 & 2 & 2 or 3 \\
\hline Mar-04 & 2 & 2 & 2 & 2 & 3 & 2 & 3 & 3 & 2 & 2 or 3 & 3 & 2 or 3 \\
\hline Abr-04 & 2 & 2 & 3 & 2 & 2 & 2 & 3 & 2 & 3 & 2 & 3 & 2 \\
\hline Mai-04 & 2 & 3 & 2 & 2 or 3 & 3 & 2 or 3 & 2 & 3 & 3 & 2 or 3 & 3 & 2 or 3 \\
\hline Jun-04 & 3 & 2 & 3 & 2 & 3 & 2 & 3 & 3 & 3 & 2 or 3 & 3 & 2 or 3 \\
\hline Jul-04 & 2 & 3 & 3 & 2 or 3 & 2 & 2 or 3 & 3 & 3 & 3 & 2 or 3 & 3 & 2 or 3 \\
\hline Ago-04 & 3 & 3 & 2 & 2 or 3 & 2 & 2 or 3 & 3 & 3 & 3 & 2 or 3 & 3 & 2 or 3 \\
\hline Set-04 & 3 & 2 & 2 & 2 & 3 & 2 & 3 & 3 & 3 & 2 or 3 & 2 & 2 or 3 \\
\hline Out-04 & 2 & 2 & 3 & 2 & 4 & 2 & 3 & 3 & 2 & 2 or 3 & 3 & 2 or 3 \\
\hline Nov-04 & 2 & 3 & 4 & 2 or 3 & 4 & 2 or 3 & 3 & 2 & 3 & 2 & 4 & 2 \\
\hline \multirow[t]{2}{*}{ Dez-04 } & 3 & 4 & 4 & 3 or 4 & 4 & 4 & 2 & 3 & 4 & 2 or 3 & 4 & 2 or 3 \\
\hline & \multicolumn{6}{|c|}{ Serpa } & \multicolumn{6}{|c|}{ Relíquias } \\
\hline Jan-04 & 1 & 1 & 2 & 1 & 2 & 1 & 2 & 2 & 2 & 2 & 2 & 2 \\
\hline Fev-04 & 1 & 2 & 2 & 2 & 2 & 2 & 2 & 2 & 2 & 2 & 2 & 2 or 3 \\
\hline Mar-04 & 2 & 2 & 2 & 2 & 2 & 2 & 2 & 2 & 2 & 2 & 2 & 2 or 3 \\
\hline Abr-04 & 2 & 2 & 2 & 2 & 2 & 2 & 2 & 2 & 2 & 2 & 2 & 2 \\
\hline Mai-04 & 2 & 2 & 2 & 2 & 2 & 2 & 2 & 2 & 2 & 2 & 2 & 2 or 3 \\
\hline Jun-04 & 2 & 2 & 2 & 2 & 2 & 2 & 2 & 2 & 2 & 2 & 2 & 2 or 3 \\
\hline Jul-04 & 2 & 2 & 2 & 2 & 2 & 2 & 2 & 2 & 2 & 2 & 2 & 2 or 3 \\
\hline Ago-04 & 2 & 2 & 2 & 2 & 2 & 2 & 2 & 2 & 2 & 2 & 2 & 2 or 3 \\
\hline Set-04 & 2 & 2 & 2 & 2 & 2 & 2 & 2 & 2 & 2 & 2 & 3 & 2 or 3 \\
\hline Out-04 & 2 & 2 & 2 & 2 & 4 & 2 & 2 & 2 & 3 & 2 & 4 & 2 or 3 \\
\hline Nov-04 & 2 & 2 & 4 & 2 & 4 & 2 & 2 & 3 & 4 & 2 or 3 & 4 & 2 \\
\hline \multirow[t]{2}{*}{ Dez-04 } & 2 & 4 & 4 & 3 or 4 & 4 & 4 & 3 & 4 & 4 & 4 & 4 & 4 \\
\hline & \multicolumn{6}{|c|}{ Castro Verde } & \multicolumn{6}{|c|}{ Martim Longo } \\
\hline Jan-04 & 1 & 1 & 1 & 1 & 2 & 1 & 1 & 1 & 1 & 1 & 1 & 1 \\
\hline Fev-04 & 1 & 1 & 2 & 1 & 2 & 1 & 1 & 1 & 1 & 1 & 1 & 1 \\
\hline Mar-04 & 1 & 2 & 2 & 2 & 2 & 2 & 1 & 1 & 1 & 1 & 2 & 1 \\
\hline Abr-04 & 2 & 2 & 2 & 2 & 2 & 2 & 1 & 1 & 2 & 1 & 1 & 1 \\
\hline Mai-04 & 2 & 2 & 2 & 2 & 2 & 2 & 1 & 2 & 1 & 2 & 1 & 2 \\
\hline Jun-04 & 2 & 2 & 2 & 2 & 2 & 2 & 2 & 1 & 1 & 1 & 1 & 1 \\
\hline Jul-04 & 2 & 2 & 2 & 2 & 2 & 2 & 1 & 1 & 1 & 1 & 1 & 1 \\
\hline Ago-04 & 2 & 2 & 2 & 2 & 2 & 2 & 1 & 1 & 1 & 1 & 1 & 1 \\
\hline Set-04 & 2 & 2 & 2 & 2 & 2 & 2 & 1 & 1 & 1 & 1 & 2 & 1 \\
\hline Out-04 & 2 & 2 & 2 & 2 & 3 & 2 & 1 & 1 & 2 & 1 & 3 & 1 \\
\hline Nov-04 & 2 & 2 & 3 & 2 & 4 & 2 & 1 & 2 & 3 & 2 & 3 & 2 \\
\hline \multirow[t]{2}{*}{ Dez-04 } & 2 & 3 & 4 & 2 or 3 & 4 & 3 or 4 & 2 & 3 & 3 & 2 or 3 & 3 & 2 or 3 \\
\hline & & Ba & rrage & da Bra & yura & & & & ão Br & e Alpor & & \\
\hline Jan-04 & 1 & 1 & 2 & 1 & 2 & 1 & 2 & 2 & 2 & 2 & 3 & 2 \\
\hline Fev-04 & 1 & 2 & 2 & 2 & 2 & 2 & 2 & 2 & 3 & 2 & 3 & 2 \\
\hline Mar-04 & 2 & 2 & 2 & 2 & 2 & 2 & 2 & 3 & 3 & 2 or 3 & 4 & 2 or 3 \\
\hline Abr-04 & 2 & 2 & 2 & 2 & 2 & 2 & 3 & 3 & 4 & 2 or 3 & 3 & 2 or 3 \\
\hline Mai-04 & 2 & 2 & 2 & 2 & 2 & 2 & 3 & 4 & 3 & 3 or 4 & 3 & 3 or 4 \\
\hline Jun-04 & 2 & 2 & 2 & 2 & 2 & 2 & 4 & 3 & 3 & 2 or 3 & 3 & 2 or 3 \\
\hline Jul-04 & 2 & 2 & 2 & 2 & 2 & 2 & 3 & 3 & 3 & 2 or 3 & 3 & 2 or 3 \\
\hline Ago-04 & 2 & 2 & 2 & 2 & 2 & 2 & 3 & 3 & 3 & 2 or 3 & 3 & 2 or 3 \\
\hline Set-04 & 2 & 2 & 2 & 2 & 3 & 2 & 3 & 3 & 3 & 2 or 3 & 4 & 2 or 3 \\
\hline Out-04 & 2 & 2 & 3 & 2 & 4 & 2 & 3 & 3 & 4 & 2 or 3 & 4 & 2 or 3 \\
\hline Nov-04 & 2 & 3 & 4 & 2 or 3 & 4 & 2 or 3 & 3 & 4 & 4 & 3 or 4 & 4 & 3 or 4 \\
\hline Dez-04 & 3 & 4 & 4 & 3 or 4 & 4 & 3 or 4 & 4 & 4 & 4 & 3 or 4 & 4 & 3 or 4 \\
\hline
\end{tabular}


probable drought class for Grândola in November was again the class 4 (severe/extreme).

\section{Results and discussion}

Table 6 presents for several rainfall stations the values of the expected number of transitions between drought classes for two consecutive months. As it can be observed, the highest values occur for the transitions that imply the maintenance of the precedent drought classes (cells in grey), i.e., transitions $1 \rightarrow 1 \rightarrow 1$, $2 \rightarrow 2 \rightarrow 2,3 \rightarrow 3 \rightarrow 3,4 \rightarrow 4 \rightarrow 4$. A strong diagonal tendency is shown in the contingency tables indicating the referred self-perpetuating characteristic trend of droughts.

The lowest values (near zero) in Table 6 refer to the direct transitions from a given drought class to another two or three categories more or less severe than the first one, e.g. from the severe/extreme drought (class 4) to near normal or non-drought (classes 2 and 1 ,

Table 8 Comparison between the observed and predicted drought classes 1 and 2 months ahead ( $t$ and $t+1)$ using odds estimates when the drought classes are known at months $t-1$ and $t-2$ for a period when a drought start dissipating (July 2005June 2006)

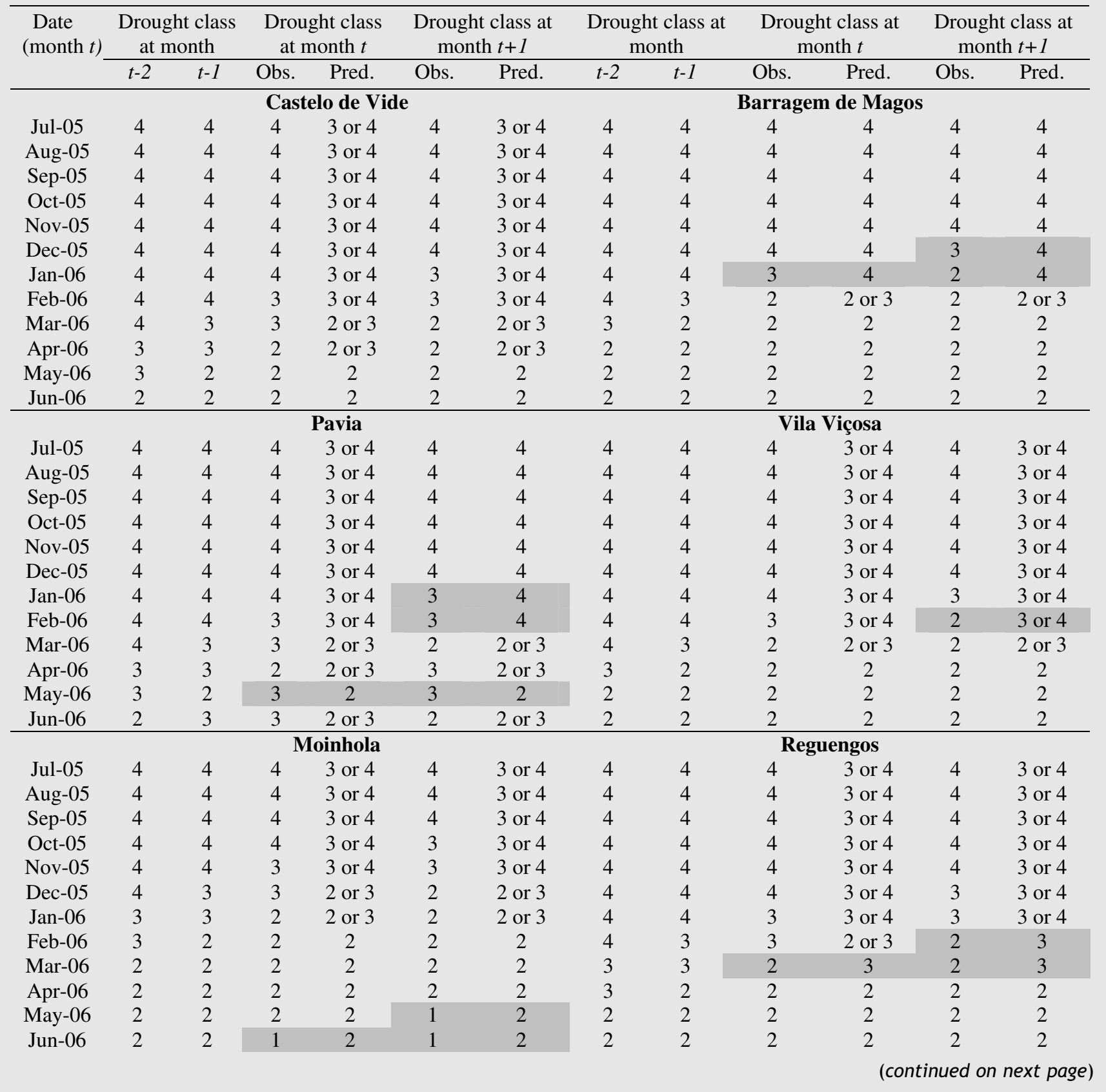


Table 8 (continued)

\begin{tabular}{|c|c|c|c|c|c|c|c|c|c|c|c|c|}
\hline \multirow[t]{2}{*}{$\begin{array}{c}\text { Date } \\
(\text { month } t)\end{array}$} & \multicolumn{2}{|c|}{$\begin{array}{c}\text { Drought class } \\
\text { at month }\end{array}$} & \multicolumn{2}{|c|}{$\begin{array}{c}\text { Drought class } \\
\text { at month } t\end{array}$} & \multicolumn{2}{|c|}{$\begin{array}{l}\text { Drought class at } \\
\text { month } t+1\end{array}$} & \multicolumn{2}{|c|}{$\begin{array}{c}\text { Drought class at } \\
\text { month }\end{array}$} & \multicolumn{2}{|c|}{$\begin{array}{c}\text { Drought class at } \\
\text { month } t\end{array}$} & \multicolumn{2}{|c|}{$\begin{array}{l}\text { Drought class at } \\
\text { month } t+1\end{array}$} \\
\hline & $t-2$ & $t-1$ & Obs. & Pred. & Obs. & Pred. & $t-2$ & $t-1$ & Obs. & Pred. & Obs. & Pred. \\
\hline & \multicolumn{6}{|c|}{ Grândola } & \multicolumn{6}{|c|}{ Viana do Alentejo } \\
\hline Jul-05 & 4 & 4 & 4 & 4 & 4 & 4 & 4 & 4 & 4 & 4 & 4 & 4 \\
\hline Aug-05 & 4 & 4 & 4 & 4 & 4 & 4 & 4 & 4 & 4 & 4 & 4 & 4 \\
\hline Sep-05 & 4 & 4 & 4 & 4 & 4 & 4 & 4 & 4 & 4 & 4 & 4 & 4 \\
\hline Oct-05 & 4 & 4 & 4 & 4 & 4 & 4 & 4 & 4 & 4 & 4 & 4 & 4 \\
\hline Nov-05 & 4 & 4 & 4 & 4 & 4 & 4 & 4 & 4 & 4 & 4 & 4 & 4 \\
\hline Dec-05 & 4 & 4 & 4 & 4 & 4 & 4 & 4 & 4 & 4 & 4 & 4 & 4 \\
\hline Jan-06 & 4 & 4 & 4 & 4 & 3 & 4 & 4 & 4 & 4 & 4 & 4 & 4 \\
\hline Feb-06 & 4 & 4 & 3 & 4 & 2 & 4 & 4 & 4 & 4 & 4 & 3 & 4 \\
\hline Mar-06 & 4 & 3 & 2 & 2 or 3 & 2 & 2 or 3 & 4 & 4 & 3 & 4 & 2 & 4 \\
\hline Apr-06 & 3 & 2 & 2 & 2 & 2 & 2 & 4 & 3 & 2 & 2 or 3 & 2 & 2 \\
\hline May-06 & 2 & 2 & 2 & 2 & 2 & 2 & 3 & 2 & 2 & 2 & 2 & 2 \\
\hline \multirow[t]{2}{*}{ Jun-06 } & 2 & 2 & 2 & 2 & 2 & 2 & 2 & 2 & 2 & 2 & 2 & 2 \\
\hline & \multicolumn{6}{|c|}{ Serpa } & \multicolumn{6}{|c|}{ Relíquias } \\
\hline Jul-05 & 4 & 4 & 4 & 3 or 4 & 4 & 4 & 4 & 4 & 4 & 4 & 4 & 4 \\
\hline Aug-05 & 4 & 4 & 4 & 3 or 4 & 4 & 4 & 4 & 4 & 4 & 4 & 4 & 4 \\
\hline Sep-05 & 4 & 4 & 4 & 3 or 4 & 4 & 4 & 4 & 4 & 4 & 4 & 4 & 4 \\
\hline Oct-05 & 4 & 4 & 4 & 3 or 4 & 3 & 4 & 4 & 4 & 4 & 4 & 4 & 4 \\
\hline Nov-05 & 4 & 4 & 3 & 3 or 4 & 3 & 4 & 4 & 4 & 4 & 4 & 3 & 4 \\
\hline Dec-05 & 4 & 3 & 3 & 2 or 3 & 2 & 3 & 4 & 4 & 3 & 4 & 2 & 4 \\
\hline Jan-06 & 3 & 3 & 2 & 3 & 2 & 3 & 4 & 3 & 2 & 2 or 3 & 2 & 2 \\
\hline Feb-06 & 3 & 2 & 2 & 2 & 2 & 2 & 3 & 2 & 2 & 2 & 2 & 2 \\
\hline Mar-06 & 2 & 2 & 2 & 2 & 2 & 2 & 2 & 2 & 2 & 2 & 2 & 2 \\
\hline Apr-06 & 2 & 2 & 2 & 2 & 2 & 2 & 2 & 2 & 2 & 2 & 2 & 2 \\
\hline May-06 & 2 & 2 & 2 & 2 & 2 & 2 & 2 & 2 & 2 & 2 & 2 & 2 \\
\hline \multirow[t]{2}{*}{ Jun-06 } & 2 & 2 & 2 & 2 & 2 & 2 & 2 & 2 & 2 & 2 & 2 & 2 \\
\hline & \multicolumn{6}{|c|}{ Castro Verde } & \multicolumn{6}{|c|}{ Martim Longo } \\
\hline Jul-05 & 4 & 4 & 4 & 4 & 4 & 4 & 4 & 4 & 4 & 4 & 4 & 4 \\
\hline Aug-05 & 4 & 4 & 4 & 4 & 4 & 4 & 4 & 4 & 4 & 4 & 4 & 4 \\
\hline Sep-05 & 4 & 4 & 4 & 4 & 4 & 4 & 4 & 4 & 4 & 4 & 4 & 4 \\
\hline Oct-05 & 4 & 4 & 4 & 4 & 3 & 4 & 4 & 4 & 4 & 4 & 3 & 4 \\
\hline Nov-05 & 4 & 4 & 3 & 4 & 4 & 4 & 4 & 4 & 3 & 4 & 2 & 4 \\
\hline Dec-05 & 4 & 3 & 4 & 2 or 3 & 3 & 2 or 3 & 4 & 3 & 2 & 2 or 3 & 2 & 2 or 3 \\
\hline Jan-06 & 3 & 4 & 3 & 4 & 2 & 4 & 3 & 2 & 2 & 2 & 2 & 2 \\
\hline Feb-06 & 4 & 3 & 2 & 2 or 3 & 2 & 2 or 3 & 2 & 2 & 2 & 2 & 2 & 2 \\
\hline Mar-06 & 3 & 2 & 2 & 2 & 2 & 2 & 2 & 2 & 2 & 2 & 1 & 2 \\
\hline Apr-06 & 2 & 2 & 2 & 2 & 2 & 2 & 2 & 2 & 1 & 2 & 2 & 2 \\
\hline May-06 & 2 & 2 & 2 & 2 & 2 & 2 & 2 & 1 & 2 & 1 & 1 & 1 \\
\hline \multirow[t]{2}{*}{ Jun-06 } & 2 & 2 & 2 & 2 & 2 & 2 & 1 & 2 & 1 & 2 & 1 & 2 \\
\hline & & & 3arras & m da B & vura & & & & ão Br & e Alport & & \\
\hline Jul-05 & 4 & 4 & 4 & 3 or 4 & 4 & 3 or 4 & 4 & 4 & 4 & 3 or 4 & 4 & 3 or 4 \\
\hline Aug-05 & 4 & 4 & 4 & 3 or 4 & 4 & 3 or 4 & 4 & 4 & 4 & 3 or 4 & 4 & 3 or 4 \\
\hline Sep-05 & 4 & 4 & 4 & 3 or 4 & 4 & 3 or 4 & 4 & 4 & 4 & 3 or 4 & 4 & 3 or 4 \\
\hline Oct-05 & 4 & 4 & 4 & 3 or 4 & 3 & 3 or 4 & 4 & 4 & 4 & 3 or 4 & 3 & 3 or 4 \\
\hline Nov-05 & 4 & 4 & 3 & 3 or 4 & 3 & 3 or 4 & 4 & 4 & 3 & 3 or 4 & 3 & 3 or 4 \\
\hline Dec-05 & 4 & 3 & 3 & 2 or 3 & 2 & 2 or 3 & 4 & 3 & 3 & 2 or 3 & 2 & 2 or 3 \\
\hline Jan-06 & 3 & 3 & 2 & 2 or 3 & 2 & 2 or 3 & 3 & 3 & 2 & 2 or 3 & 2 & 2 or 3 \\
\hline Feb-06 & 3 & 2 & 2 & 2 & 2 & 2 & 3 & 2 & 2 & 2 & 2 & 2 \\
\hline Mar-06 & 2 & 2 & 2 & 2 & 2 & 2 & 2 & 2 & 2 & 2 & 2 & 2 \\
\hline Apr-06 & 2 & 2 & 2 & 2 & 2 & 2 & 2 & 2 & 2 & 2 & 2 & 2 \\
\hline Мay-06 & 2 & 2 & 2 & 2 & 1 & 2 & 2 & 2 & 2 & 2 & 1 & 2 \\
\hline Jun-06 & 2 & 2 & 2 & 2 & 1 & 2 & 2 & 2 & 1 & 2 & 2 & 2 \\
\hline
\end{tabular}

respectively). These transitions have a very low probability because droughts do not initiate or dissipate suddenly.
Tables 7 and 8 present the validation of the loglinear modeling by comparing the actual SPI drought class 
categories calculated from observed rainfall data with the predictions 1 and 2 months ahead for the same months computed through the odds estimates. Predictions with 2-month lead, at month $t+1$, base upon the observed value for month $t-1$ and the predicted value for month $t$. The selected periods for testing concern the last observed drought in the region, called the 2005 drought. Table 7 refers to a 12-month period, January-December 2004, when that drought was initiating and developing with increased severity, and Table 8 , refers to another 12-month period, July 2005-June 2006, which starts when the drought was extreme and ends when the drought was slowly dissipating. Twelve-month periods are shown to include both the dry and wet seasons. The sites cover the entire Alentejo region and part of Algarve, thus not referring to any particular climate in the area. For the drought initiation and development period (Table 7), the drought severity classes in the first month are 1, 2 or 3 (non-drought, near normal and moderate drought, respectively), and all but one end at class 4 (severe and extremely severe drought). The dissipation test period starts with all sites in class 4 and ends with them all in class 2 at the month $t+1$; in month $t$ all were at the class 2 but one in class 1 . Thus, the periods selected give a true picture of both the drought initiation and development and drought dissipation.

For each site, are presented the observed drought classes at months $t-2$ and $t-1$, and the observed and predicted drought classes for months $t$ and $t+1$, i.e., with 1 - and 2 month lead. When the probability that a site will be in a given drought class is not significantly different from the probability that it would be in a next severity class; then the prediction refers to both drought classes, e.g. "2 or 3"' meaning that probabilities for transitions into the classes 2 or 3 are similar.

Results in Tables 7 and 8 show a coincidence between the predicted and the actual drought classes for the large majority of the months. The non-grey cells refer to the cases when the predicted drought class was vindicated. Cells in grey refer to cases where this vindication does not hold but the predicted classes are the neighboring ones with very few exceptions. As expected, more less good predictions refer to the 2-month lead time. Disagreements often refer to conditions when a decrease or increase of the drought class category breaks with the drought class established in the preceding 2 months, which correspond to an increase or decrease in rainfall for the months under prevision. Results generally do not give a trend of decreased or increased severity opposed to the observed trend but with few exceptions, mainly for predictions with 2-month lead. However, this happens when the SPI values are near the upper or lower limit of a class, when a relatively small increase in the precipitation deficit or in rainfall moves the drought severity to the superior or inferior class of severity.

Table 7 shows that most difficult predictions of drought class transitions when drought severity is increasing occur in the autumn months, where the rainfall season starts after the dry summer and where the monthly precipitation is expected to be high (cf. Fig. 1). It is during that period that monthly precipitation deficits produce strong decreases in SPI values, thus transitions into clas- ses of high severity. For the period of drought dissipation (Table 8), predictions show to be more difficult for the Winter months. This may be explained by the fact that the model, having learnt from the preceding months that a high severity class is established produces predictions for the next months with a lag, but is able to predict the trend for dissipation from then after. The lag between observed and predicted drought classes relates with the diagonal tendency shown in the contingency table given that recent drought situations tend to remain.

Observing the predictions in Table 7 , it is possible to note that they could improve the information resulting from monitoring using precipitation data and related drought indices. In particular, it could be possible to alert farmers and water managers at early autumn months, by the beginning of the agricultural year, about the likely establishment of that drought. In reality a drought condition was only declared by March of 2005, thus late relative to farming decisions, when it was already attaining the maximal severity. Similarly, results in Table 8 show that the trend for dissipation could only be confirmed at the end of winter, but the drought was officially terminated by January, which has been a risky decision. These results show that using a monthly prediction of drought severity classes transitions may be useful to better adopt a risk management approach to droughts. However, other stochastic and weather regime models may also be used.

\section{Conclusions}

The loglinear models for three-dimensional contingency tables show to be a useful tool to predict drought class transitions in a short term, i.e., knowing the drought class values for two precedent months it is possible to make reliable predictions for drought class in the two following months. Only for a few cases, the predicted and the actual drought classes did not match. Often, this happens when the SPI value is near the upper or lower boundary of the class and easy change to the nearby class when the precipitation deficit increases or higher precipitation occurs. Results show that predictions of drought class transitions are able to describe the trend of drought initiation and development as well as the trend for drought dissipation. The predictions show a lag relative to the observed drought classes during the Autumn months when a drought is developing, and for the Winter months when a drought is dissipating, which occur more often in case of predictions with 2-month lead. However, in general, results show that three-dimensions loglinear modeling of monthly drought class transitions is able to capture the trends for both drought initiation and establishment and drought dissipation. The approach results therefore appropriate to strengthen the usefulness of drought monitoring and related information to water managers and users, to support their decisions on drought mitigation measures.

Loglinear modeling to predict more than two consecutive drought class implies a very large number of model parameters, the respective contingency tables become 
complicate, and the interpretation of the model results difficult. Hence, it is not foreseen to use loglinear models to increase the lead time of predictions. However, because precipitation in Portugal occurs predominantly during the autumn and winter, and that spring and summer are in general dry, it is aimed to consider for future work to include a fourth category in the contingency tables, representing the period of the year, i.e., the wet and dry seasons. This adding up might introduce an improvement in the predictions since the probability of each drought class transition depends upon the period of the year. It may also be considered the use of SPI data computed with and the Research Contract INTERREG III B MEDOC 200202-4.4-1-084.

\section{Appendix 1. Backward elimination method}

Once adjusted the QA complete model (Eq. (1)) the following steps illustrate the backward elimination method applied to data of the Grândola site:

Step 1 - Starting by testing the highest interactions, the $\tau$ parameter representing the interaction between the three categories of the contingency tables, is the first to be tested

\begin{tabular}{llllllll}
\hline $\begin{array}{l}\text { Parameter } \\
\text { eliminated }\end{array}$ & $\begin{array}{l}\text { Model residual } \\
\text { deviance }\end{array}$ & d.f. & $\begin{array}{l}\text { Model (1) residual } \\
\text { deviance }\end{array}$ & d.f. (1) & $\begin{array}{l}\text { Residual deviance } \\
\text { difference }\end{array}$ & d.f. difference & $p$-Value \\
\hline$\tau$ & 25.89 & 35 & 25.85 & 34 & $25.89-25.85=0.04$ & $35-34=1$ & 0.8415 \\
\hline
\end{tabular}

a shorter time scale and produce the predictions from results obtained from both 12-month and shorter time scales.

In addition to loglinear modeling, it is foreseen to adopt other stochastic and weather regime prediction tools aiming at further developing drought risk management policies and measures. The usefulness of using Markov chains modeling is already demonstrated for short time predictions. Combining results of stochastic modeling with information derived from atmospheric circulation for elimination:

Considering that the $p$-value $>0.05$, the null hypotheses $H_{0}: \tau=0$ is not rejected, thus $\tau u_{i} v_{j} w_{k}$ is not significantly $\neq 0$, the simplified model is not rejected and the parameter is eliminated. Therefore, the QA model simplifies into:

$$
\begin{aligned}
\log E_{i j k}= & \lambda+\lambda_{i}^{\mathrm{A}}+\lambda_{j}^{\mathrm{B}}+\lambda_{k}^{\mathrm{C}}+\beta u_{i} v_{j}+\alpha u_{i} w_{k}+\eta v_{j} w_{k}+\delta_{1 i} l(i=j) \\
& +\delta_{2 i} l(i=k)+\delta_{3 j} l(j=k)+\delta_{4 i} l(i=j=k)
\end{aligned}
$$

\begin{tabular}{|c|c|c|c|c|c|c|c|}
\hline $\begin{array}{l}\text { Parameter } \\
\text { eliminated }\end{array}$ & $\begin{array}{l}\text { Model residual } \\
\text { deviance }\end{array}$ & d.f. & $\begin{array}{l}\text { Model (A1) residual } \\
\text { deviance }\end{array}$ & d.f. (A1) & Residual deviance difference & d.f. difference & $p$-Value \\
\hline$\beta$ & 82.45 & 36 & 25.89 & 35 & $82.45-25.89=56.56$ & $36-35=1$ & 0.0000 \\
\hline$\alpha$ & 29.43 & 36 & & & $29.43-25.89=3.54$ & $36-35=1$ & 0.0599 \\
\hline$\eta$ & 82.72 & 36 & & & $82.72-25.89=56.56$ & $36-35=1$ & 0.0000 \\
\hline
\end{tabular}

Step 2 - Testing the $\beta, \alpha$ and $\eta$ parameters, correspond- models, mainly focusing weather regime transitions, is therefore the main objective of research related with drought predictions.

\section{Acknowledgements}

Data used in this study were made available by the Institute for Water (INAG), Portugal. This study was funded through the National Project PEDIZA 1999.64.006326.1, ing to the interactions between two categories:

Considering that the $p$-value of the sub-model without the $\alpha$ parameter is $>0.05, H_{0}: \alpha=0$ is not rejected, thus the $\alpha u_{i} w_{k}$ parameter is eliminated; the QA model becomes:

$$
\begin{aligned}
\log E_{i j k}= & \lambda+\lambda_{i}^{\mathrm{A}}+\lambda_{j}^{\mathrm{B}}+\lambda_{k}^{\mathrm{C}}+\beta u_{i} v_{j}+\eta v_{j} w_{k}+\delta_{1 i} l(i=j) \\
& +\delta_{2 i} l(i=k)+\delta_{3 j} l(j=k)+\delta_{4 i} l(i=j=k)
\end{aligned}
$$

Step 3 - After elimination of $\alpha$, it is necessary to test again the $\beta$ and $\eta$ parameters:

\begin{tabular}{llllllll}
\hline Parameter eliminated & $\begin{array}{l}\text { Model residual } \\
\text { deviance }\end{array}$ & d.f. & $\begin{array}{l}\text { Model (A2) residual } \\
\text { deviance }\end{array}$ & d.f. (A2) & $\begin{array}{l}\text { Residual deviance } \\
\text { difference }\end{array}$ & d.f. difference & $p$-Value \\
\hline$\beta$ & 96.30 & 37 & 29.43 & 36 & $96.30-29.43=66.87$ & $37-36=1$ & 0.0000 \\
$\eta$ & 96.33 & 37 & & & $96.33-29.43=66.90$ & $37-36=1$ & 0.0000 \\
\hline
\end{tabular}


Given that none of the $p$-values are $>0.05, H_{0}: \beta=0$ and $H_{0}: \eta=0$ are rejected, thus these parameters are kept and the model $(A 2)$ is retained.

Step $4-$ Testing the $\delta_{1 i}, \delta_{2 i}, \delta_{3 j}$ and $\delta_{4 i}$ parameters corresponding to the diagonal effects between categories in contingency tables:
Cancelliere, A., Di Mauro, G., Bonaccorso, B., Rossi, G., 2007. Drought forecasting using the Standardized Precipitation Index. Water Resour. Manage. 21 (5), 801-819.

Cordery, I., 1999. Long range forecasting of low rainfall. Int. J. Climatol. 19 (5), 463-470.

Cordery, I., McCall, M., 2000. A model for forecasting drought from teleconnections. Water Resour. Res. 36, 763-768.

\begin{tabular}{|c|c|c|c|c|c|c|c|}
\hline $\begin{array}{l}\text { Parameter } \\
\text { eliminated }\end{array}$ & $\begin{array}{l}\text { Model residual } \\
\text { deviance }\end{array}$ & d.f. & $\begin{array}{l}\text { Model (A2) residual } \\
\text { deviance }\end{array}$ & d.f. (A2) & Residual deviance difference & d.f. difference & $p$-Value \\
\hline$\delta_{1 i}$ & 37.21 & 40 & 29.43 & 36 & $37.21-29.43=7.78$ & $40-36=4$ & 0.1000 \\
\hline$\delta_{2 i}$ & 32.28 & 40 & & & $32.28-29.43=2.85$ & $40-36=4$ & 0.5832 \\
\hline$\delta_{3 j}$ & 37.15 & 40 & & & $37.15-29.43=7.72$ & $40-36=4$ & 0.1024 \\
\hline$\delta_{4 i}$ & 30.34 & 40 & & & $30.34-29.43=0.91$ & $40-36=4$ & 0.9231 \\
\hline
\end{tabular}

All the sub-models corresponding to the elimination of each $\delta$ parameters have $p$-value $>0.05$. However, given that only one parameter can be eliminated at each time, the elimination of $\delta_{4 i}$ is selected because it has the highest $p$-value. Thus, the model simplifies into:

$$
\begin{aligned}
\log E_{i j k}= & \lambda+\lambda_{i}^{\mathrm{A}}+\lambda_{j}^{\mathrm{B}}+\lambda_{k}^{\mathrm{C}}+\beta u_{i} v_{j}+\eta v_{j} w_{k}+\delta_{1 i} I(i=j) \\
& +\delta_{2 i} I(i=k)+\delta_{3 j} I(j=k)
\end{aligned}
$$

Step 5 - After $\delta_{4 i}$ elimination, it is necessary to test again the $\delta_{1 i}, \delta_{2 i}$ and $\delta_{3 j}$ parameters:

Given that none of the $p$-values are $>0.05, H_{0}: \delta_{j i}=0$, $j=1,2,3$ are rejected, thus none of these parameters can be eliminated and the final QA model is given by Eq. (A3).
Deloncle, A., Berk, R., D’Andrea, F., Ghil, M., 2007. Weather regime prediction using statistical learning. J. Atmos. Sci. 64 (5), 1619-1635.

Hayes, M.J., 2006. Drought indices. <http://drought.unl.edu/ whatis/indices.htm>.

Hayes, M.J., Svoboda, M., Le Comte, D., Redmond, K.T., Pasteris, P., 2007. Drought monitoring: new tools for the 21st century. In: Wilhite, D.A. (Ed.), Drought and Water Crisis. Science, Technology, and Management Issues. Taylor \& Francis, Boca Raton, pp. 53-69.

Helsel, D.R., Hirsch, R.M., 1992. Statistical Methods in Water Resources. Elsevier, Amsterdam, 522 pp..

Kim, T.W., Valdés, J.B., Nijssen, B., Roncayolo, D., 2006. Quantification of linkages between large-scale climatic patterns and precipitation in the Colorado River Basin. J. Hydrol. 321, 173-186.

Kondrashov, D., Ide, K., Ghil, M., 2004. Weather regimes and preferred transition paths in a three-level quasigeotrophic model. J. Atmos. Sci., 61.

\begin{tabular}{llllllll}
\hline $\begin{array}{l}\text { Parameter } \\
\text { eliminated }\end{array}$ & $\begin{array}{l}\text { Model residual } \\
\text { deviance }\end{array}$ & d.f. & $\begin{array}{l}\text { Model (A3) residual } \\
\text { deviance }\end{array}$ & d.f. (A3) & $\begin{array}{l}\text { Residual deviance } \\
\text { difference }\end{array}$ & d.f. difference & $p$-Value \\
\hline$\delta_{1 i}$ & 57.76 & 44 & 30.34 & 40 & $57.76-30.34=27.42$ & $44-40=4$ & 0.0000 \\
$\delta_{2 i}$ & 40.51 & 44 & & & $40.51-30.34=10.17$ & $44-40=4$ & 0.0377 \\
$\delta_{3 j}$ & 57.68 & 44 & & $57.68-30.34=27.34$ & $44-40=4$ & 0.0000 \\
\hline
\end{tabular}

\section{References}

Agresti, A., 1990. Categorical Data Analysis. John Wiley \& Sons, New York.

AMS, 2004. Meteorological drought. Bull. Am. Meteorol. Soc. 85. <http://www.ametsoc.org/POLICY/droughstatementfinal0304. html $>$.

Bhattacharya, R.N., Chan, N.H., 1996. Comparisons of chisquare, Edgeworth expansions and bootstrap approximations to the distribution of the frequency chisquare. Sankhyã: Indian J. Stat. Ser. A 58, 57-68.

Bordi, I., Sutera, A., 2007. Drought monitoring and forecasting at large scale. In: Rossi, G., Vega, T., Bonaccorso, B. (Eds.), Methods and Tools for Drought Analysis and Management. Springer, Dordrecht, pp. 3-27.

Cacciamani, C., Morgillo, A., Marchesi, S., Pavan, V., 2007. Monitoring and forecasting drought on a regional scale: EmiliaRomagna Region. In: Rossi, G., Vega, T., Bonaccorso, B. (Eds.), Methods and Tools for Drought Analysis and Management. Springer, Dordrecht, pp. 29-48.
McKee, T.B., Doesken, N.J., Kleist, J., 1993. The relationship of drought frequency and duration to time scales. In: Proceedings of the Eighth Conference on Applied Climatology. Am. Meteor. Soc., Boston, pp. 179-184.

McKee, T.B., Doesken, N.J., Kleist, J., 1995. Drought monitoring with multiple time scales. In: Proceedings of the Ninth Conference on Applied Climatology. Am. Meteor. Soc., Boston, pp. 233-236.

Mishra, A.K., Desai, V.R., 2006. Drought forecasting using feed-forward recursive neural network. Ecol. Modell. 198, 127-138.

Moreira, E.E., Paulo, A.A., Pereira, L.S., Mexia, J.T., 2006. Analysis of SPI drought class transitions using loglinear models. J. Hydrol. 331, 349-359.

National Drought Mitigation Center (NDMC), 2006. What is drought? National Drought Mitigation Center. <http://drought.unl.edu/ whatis/what.htm>.

Nelder, J.A., 1974. Loglinear models for contingency tables: a generalization of classical least squares. Appl. Stat. 23, 323-329. 
Nichols, N., Coughlan, M.J., Monnik, K., 2005. The challenge of climate prediction in mitigating drought impacts. In: Wilhite, D.A. (Ed.), Drought and Water Crisis. Science Technology, and Management Issues. Taylor \& Francis, Boca Raton, pp. 33-51.

NSSTC, 2003. NASA working to take the guesswork out of long-term drought prediction. <http://Www.msfc.nasa.gov/news/NSSTC/ news/releases/2003/N03-008.html>.

Ogallo, L.A., Boulahya, M.S., Keane, T., 2000. Applications of seasonal to interannual climate prediction in agricultural planning and operations. Agric. Forest Meteorol. 103, 159166.

Paulo, A.A., Pereira, L.S., 2006. Drought concepts and characterization: comparing drought indices applied at local and regional Scales. Water Int. 31 (1), 37-49.

Paulo, A.A., Pereira, L.S., 2007. Prediction of SPI drought class transitions using Markov chains. Water Resour. Manage. doi:10.1007/s11269-006-9129-9.

Paulo, A.A., Pereira, L.S., Matias, P.G., 2003. Analysis of local and regional droughts in southern Portugal using the theory of runs and the Standardized Precipitation Index. In: Rossi, G., Cancelliere, A., Pereira, L.S., Oweis, T., Shatanawi, M., Zairi, A. (Eds.), Tools for Drought Mitigation in Mediterranean Regions. Kluwer, Dordrecht, pp. 55-78.

Paulo, A.A., Ferreira, E., Coelho, C., Pereira, L.S., 2005. Drought class transition analysis through Markov and Loglinear models, an approach to early warning. Agric. Water Manage. 77, 59-81.

Pereira, L.S., Cordery, I., lacovides, I., 2002. Coping with water scarcity. UNESCO IHP VI, Technical Documents in Hydrology 58, UNESCO, Paris.

Rao, C.R., 1973. Linear Statistical Inference and its Applications, second ed. Wiley, New York.

Santos, J.A., Corte-Real, J., Leite, S.M., 2005. Weather regimes and their connection to the winter rainfall in Portugal. Int. J. Climatol. 25 (1), 33-50.
Santos, J., Corte-Real, J., Leite, S., 2006. Atmospheric large-scale dynamics during the 2004/2005 winter drought in Portugal. Int. J. Climatol. doi:10.1002/joc. 1425.

Steinemann, A.C., 2006. Using climate forecasts for drought management. J. Appl. Meteorol. Climatol. 45 (10), 1353-1361.

Tadesse, T., Wilhite, D.A., Hayes, M.J., Harms, S.K., Goddard, S., 2005. Discovering associations between climatic and oceanic parameters to monitor drought in Nebraska using data-mining techniques. J. Climate 18 (10), 1541-1550.

Thyer, M., Frost, A.J., Kuczera, G., 2006. Parameter estimation and model identification for stochastic models of annual hydrological data: is the observed record long enough? J. Hydrol. 330, 313328.

Trigo, R.M., Pozo-Vázquez, D., Osborn, T.J., Castro-Díez, Y., Gámiz-Fortis, S., Esteban-Parra, M.J., 2004. North Atlantic oscillation influence on precipitation, river flow and water resources in the Iberian Peninsula. Int. J. Climatol. 24 (8), 925944.

Vogt, J.V., Somma, F. (Eds.), 2000. Drought and Drought Mitigation in Europe. Kluwer, Dordrecht.

Wedgbrow, C.S., Wilby, R.L., Fox, H.R., O'Hare, G., 2002. Prospects for seasonal forecasting of summer drought and low river flow anomalies in England and Wales. Int. J. Climatol. 22 (2), 219-236.

Wilhite, D.A., 2005. Drought policy and preparedness: the Australian experience in an international context. In: Botterill, L.C., Wilhite, D.A. (Eds.), From Disaster Response to Risk Management: Australia's National Drought Policy. Springer, Dordrecht, pp. 157-183.

Wilhite, D.A., Sivakumar, M.V.K., Wood, D.A. (Eds.), 2000. Early warning systems for drought preparedness and drought management. Proceedings of an Expert Group Meeting, Lisbon. World Meteorological Organization, Geneva. <http://drought.unl.edu/ monitor/EWS/EWS_WMO.html>.

Yevjevich, V., Cunha, L.V., Vlachos, E. (Eds.), 1983. Coping with Droughts. Water Resources Publications, Littleton. 